\title{
Mercury distribution in different tissues and trophic levels of fish from a tropical reservoir, Brazil
}

\author{
Daniele Kasper ${ }^{1}$, Elisabete Fernandes Albuquerque Palermo ${ }^{1}$, \\ Ana Carolina Monteiro Iozzi Dias², Gustavo Luiz Ferreira², \\ Rafael Pereira Leitão ${ }^{3}$, Christina Wyss Castelo Branco² and Olaf Malm
}

Concentrations of organic (OrgHg) and inorganic mercury (InorgHg) were assessed in different fish tissues (liver, muscle, kidney, gut and gonads) and trophic levels collected in an impacted tropical reservoir in southeastern Brazil. Organic mercury concentrations in muscle were remarkably higher in the carnivorous species Hoplias malabaricus and Oligosarcus hepsetus. The ratios of OrgHg in relation to total mercury (\%OrgHg) in muscle also varied according to the species trophic level: $93 \%$ for carnivores, $84 \%$ for omnivores, $73 \%$ for algivores/planktivores and $58 \%$ for detritivores. The $\%$ OrgHg in the gut tissue of carnivores (78\%) was much higher than that found in omnivores (30\%), possibly reflecting a process of trophic biomagnification in the reservoir. On the other hand, the InorgHg concentrations in muscle decreased with the trophic level increase, suggesting that this form of mercury did not biomagnify through the food web. Gonads contained the least total mercury, and approximately all of this mercury was represented by the organic form (83 to 98\%). The kidney and the liver of all fish species contained less than $50 \%$ OrgHg. We suggest that the low $\% \mathrm{OrgHg}$ in the liver is related to different capacities or strategies of OrgHg detoxification by the fish.

Concentrações de mercúrio orgânico (OrgHg) e inorgânico (InorgHg) foram avaliadas em diferentes tecidos e níveis tróficos de peixes (fígado, músculo, rim, trato digestivo e gônadas) coletados em um reservatório tropical impactado, no sudeste do Brasil. Concentrações de OrgHg no músculo foram notavelmente maiores em carnívoros (Hoplias malabaricus e Oligosarcus hepsetus). As porcentagens de OrgHg em relação ao mercúrio total (\%OrgHg) no músculo também variaram de acordo com o nível trófico das espécies: $93 \%$ para os carnívoros, 84\% para os onívoros, 73\% para os algívoros/planctívoros e 58\% para os peixes detritívoros. Além disso, a \%OrgHg encontrada no trato digestivo dos peixes carnívoros (78\%) foi substancialmente superior a encontrada nos onívoros (30\%), possivelmente refletindo um processo de biomagnificação trófica no reservatório. Por outro lado, as concentrações de InorgHg no músculo diminuíram com o aumento do nível trófico, sugerindo que esta forma do mercúrio não biomagnificou ao longo da cadeia alimentar. As gônadas apresentaram as menores concentrações de mercúrio total e grande parte deste estava na forma orgânica (83 a 98\%). Por outro lado, rins e fígado de todas as espécies de peixes apresentaram menos que $50 \%$ de OrgHg. Sugere-se que a baixa \%OrgHg no fígado possa estar relacionada às diferentes capacidades ou estratégias de destoxificação do OrgHg nesses peixes.

Key words: Feeding habits, Hydroelectric, Mercury species, Biomagnification, Bioaccumulation.

\footnotetext{
${ }^{1}$ Laboratório de Radioisótopos Eduardo Penna Franca, Instituto de Biofísica Carlos Chagas Filho, Universidade Federal do Rio de Janeiro (UFRJ). Ilha do Fundão, 21941-902 Rio de Janeiro, RJ, Brazil. kasperdani@yahoo.com.br (DK), elisa@biof.ufrj.br (EFAP), olaf@biof.ufrj.br (OM)

${ }^{2}$ NEL - Núcleo de Estudos Limnológicos, Escola de Ciências Biológicas, Universidade Federal do Estado do Rio de Janeiro (UNIRIO). Av. Pasteur, 458 sala 403, 22290-240 Rio de Janeiro, RJ, Brazil. anacarol_iozzi@yahoo.com.br (ACMID), gustavoferreirabio@yahoo.com.br (GLF), cbranco@domain.com.br (CWCB)

${ }^{3}$ Coordenação de Pesquisas em Biologia Aquática, Instituto Nacional de Pesquisas da Amazônia (INPA), 69083-970 Manaus, AM, Brazil. ecorafa@gmail.com
} 


\section{Introduction}

Mercury is a non-essential heavy metal, and both its organic and inorganic forms bioaccumulate (Stemberger \& Chen, 1998). The potential determinants of mercury accumulation in fish include trophic level; feeding habits; environmental factors such as $\mathrm{pH}$, DOC, and temperature; and biological parameters such as length, weight, and age (Svobodová et al., 1999; Kehrig et al., 2001; Belger \& Forsberg, 2006).

Besides the bioaccumulation of mercury, its biomagnification across food chains is widely recognized (e.g. Bargagli et al., 1998; McIntyre \& Beauchamp, 2007). According to Schetagne et al. (2000), feeding is the main pathway of methylmercury to fish. Methylmercury concentrations in fish can be up to 100000 times higher than the water concentration (World Health Organization, 1990). Therefore, to understand the mercury concentrations in fish, it is important to know their trophic level.

The contamination of aquatic biota by mercury has been widely studied. Because of the direct relationship with human health, most of those studies consider only the muscle (since this tissue is the main edible part). On the other hand, research on different tissues is important to understand the major targets in contamination by metals and their dynamics in the organisms themselves. However, this approach is still seldom used; some explorations of mercury contamination in different tissues have been conducted with marine mammals, because of their phylogenetic closeness to humans. Studies on freshwater fish, in particular, are rarer (e.g., Svobodová et al., 1999; Maury-Brachet et al., 2006).

Understanding which organs accumulate mercury, and which are the predominant $\mathrm{Hg}$ chemical species (organic or inorganic), is fundamental for basic comprehension of $\mathrm{Hg}$ toxicokinetics. The possible differentiations of mercury dynamics in these organs among different trophic levels are nearly unknown. Several studies have identified mercury biomagnification in a wide range of levels of organization, in very different trophic positions and compartments, such as water-plankton-fish-marine mammals. Only a few studies have examined this process using a small-scale approach (e.g., Kehrig et al., 2009, for a plankton community). Fish are suitable organisms to evaluate all these questions, because they can be engaged in diverse trophic levels, and the food habits of many species are already known. Hence, the objectives of the present study were to assess: (1) the mercury biomagnification by fishes that belong to different trophic levels in the Vigário reservoir, and (2) the distribution of inorganic and organic mercury in different fish tissues (muscle, kidney, gonad, liver, and gut), according to the trophic level of the fishes.

\section{Material and Methods}

The study was conducted in Vigário reservoir (2241'S $43^{\circ} 52^{\prime}$ W), southern Rio de Janeiro State, Brazil (Fig. 1). This artificial lake is surrounded by an urban landscape of villages and roads, and is intensively colonized by aquatic macrophytes because of its eutrophication. The main uses of this reservoir are as a water supply for the human population, generation of electrical power, and fishing activity. The Vigário reservoir receives water from the Santana reservoir, which in turn receives water from the Piraí $\left(20 \mathrm{~m}^{3} / \mathrm{s}\right)$ and Paraíba do Sul rivers (up to $\sim 160 \mathrm{~m}^{3} / \mathrm{s}$ ) (FEEMA, 1991). The Paraíba do Sul

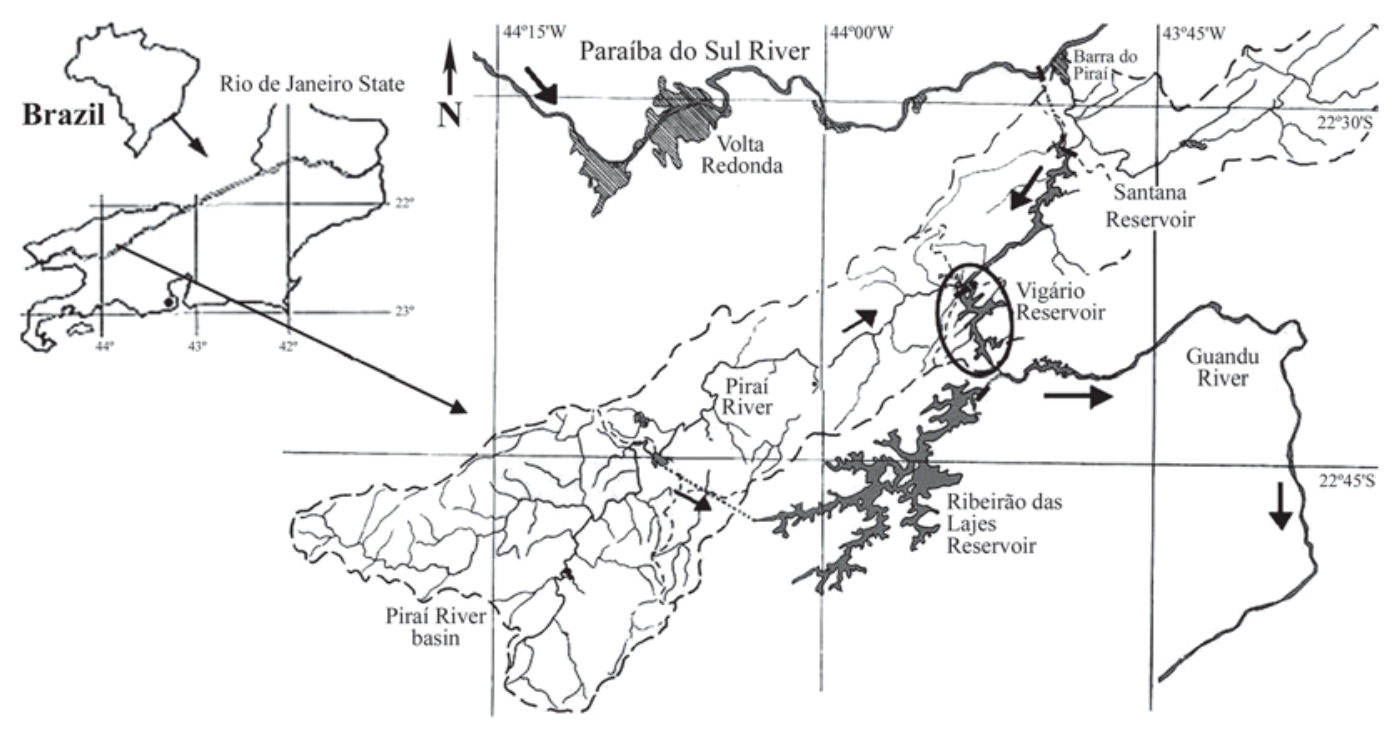

Fig. 1. Map of Vigário reservoir, showing its drainage basin (Piraí river, Paraíba do Sul river and Santana reservoir). Black arrows indicate the water flow. (Source: Gomes et al., 2008). 
river basin is urbanized and surrounded by a large industrial complex, composed of potentially heavy-metal polluting industries.

Five fish species were collected in April 2004 (beginning of the dry season) and analyzed for mercury concentrations: Hoplias malabaricus (Bloch, 1794), Oligosarcus hepsetus (Cuvier, 1829), Astyanax aff. bimaculatus (Linnaeus, 1758), Loricariichthys castaneus (Castelnau, 1855), and Rhamdia quelen (Quoy \& Gaimard, 1824). These fish were weighed, measured (standard length), and killed by freezing immediately after collection. The sex was determined through macroscopic examination of the gonads (according to Vazzoler, 1996). All specimens analyzed were adult females. In order to avoid a size effect on the mercury analyses, we selected individuals (from each species) with maximum similarity in standard length and weight, as far as it was possible. Additionally, Pearson's test was used to evaluate the existence of correlations between THg concentrations in muscle and these two biological parameters. All dissected tissues (muscle, gonad, kidney, liver, and gut) were kept in individual plastic bags and stored frozen at $-18^{\circ} \mathrm{C}$ until mercury (Hg) analysis. These five tissues could not be removed in all fish species analyzed. Because of the small size of some specimens, their tissues had insufficient mass for mercury analyses. In algivores/planktivores, for example, only muscle tissue had an adequate amount of mass. Samples were collected, stored, and analyzed using ultra-clean techniques, including the use of polyethylene gloves, acid pre-treatment of laboratory material, and the use of distilled and de-ionized water and laboratory grade chemicals for preparing solutions.

The total (THg) and organic mercury (OrgHg) contents were determined according to Bastos et al. (1998) and Uthe et al. (1972), respectively. In both methods, Hg was determined and quantified by Cold Vapor Atomic Absorption Spectrometry with a Flow Injection Mercury System (FIMS) - FIAS 400 (Perkin Elmer, USA), using sodium borohydride as a reducing agent. Total mercury concentrations correspond to the sum of organic and inorganic mercury (InorgHg) concentrations. Therefore, the InorgHg concentrations were calculated by subtracting the OrgHg from the THg concentrations in each sample. The OrgHg ratio $(\% \mathrm{OrgHg})$ represents the ratio of organic mercury in relation to THg.

Reproducibility and accuracy of the mercury methodologies utilized were determined by means of duplicate analyses. Analytical quality control was carried out with the use of certified references (DORM-2, dogfish muscle, and TORT-2, lobster hepatopancreas, both from the National Research Council of Canada). The detection limits of THg and OrgHg were 0.05 and $0.04 \mu \mathrm{g} / \mathrm{l}$, respectively, corresponding to three times the standard deviation of the blanks.

In order to assign the fish species to trophic levels, we conducted a diet analyses on the same specimens assessed for the Hg concentrations. Additional information based on specific literature was used for the trophic-level determination. Food items were identified to the lowest suitable taxonomic category and quantified according to Branco et al. (1997). Stomach (or the upper third of the gut) contents were analyzed to estimate the relative abundance of the food items (Hyslop, 1980). All the mercury analyses in the following discussion were based on the trophic levels, rather than on the taxonomic species.

Kruskal-Wallis (KW), and subsequently Dunn's multiple comparison tests (post hoc), were used to test the differences between $\mathrm{Hg}$ concentrations in the muscle of fish of different trophic levels. To test for differences in OrgHg versus InorgHg concentrations within tissues, a paired t test was used. A paired t test was also conducted in order to test for differences in $\mathrm{Hg}$ concentration between two tissues independently (e.g., muscle vs. liver; muscle vs. gut) (Zar, $1984)$. All tests were conducted at a significance level of $5 \%$ $(\alpha=0.05)$. Statistical analysis could not be conducted with the kidney Hg concentrations because of the small number of samples of this tissue. A ratio of organic mercury concentrations between liver and gut was calculated in omnivores and carnivores. Voucher specimens were deposited at the Museu Nacional do Rio de Janeiro (UFRJ), under the code MNRJ 28413, MNRJ 35445 and MNRJ 35448.

\section{Results}

According to the diet analyses, the fish species belonged to four trophic levels: detritivores (Loricariichthys castaneus), omnivores (Rhamdia quelen), algivores/ planktivores (Astyanax aff. bimaculatus), and carnivores (Hoplias malabaricus and Oligosarcus hepsetus). The relative abundances of items of animal origin in the diet were $21,41,53$, and $100 \%$ for detritivores, algivores/planktivores, omnivores, and carnivores (exclusively O. hepsetus), respectively.

The items most frequently found in the stomach of $L$. castaneus were sand grains (50\%), detritus (19\%), and insects (13\%). The predominant insects were chironomid larvae from sediments. Testate amoebae (6\%), microcrustaceans (6\%), and algae (4\%) associated with substrates were also found in the stomach content.

The items ingested by $O$. hepsetus were: insects (insect remains - $47.2 \%$, hemipterans - $4 \%$ ); animal debris, mainly fish (45.7\%); and cladocerans (2.5\%). All the stomachs of $H$. malabaricus were empty. However, according to previous studies (e.g., Aguiaro \& Caramaschi, 1998; Novakowski et al., 2007; Sánchez-Botero et al., 2007) of the feeding habits of $H$. malabaricus in this or other regions, this species is considered a macrophagous carnivore.

Rhamdia quelen was considered an omnivore, since the proportions of stomach items were divided among: animal debris, mainly benthic invertebrates (43.4\%); plant debris (22.8\%); filamentous algae (15.7\%); and zooplankton remains (8.3\%, primarily cladocerans).

The most important food items found in the stomach of $A$. 
aff. bimaculatus were algae (41.7\%) and zooplankton (cladoceran remains - 27.1\% and Bosmina - 13.6\%), and therefore this species was characterized as algivorous/ planktivorous. Most of the algae were filamentous, and probably associated with the periphytic community that colonizes the macrophyte banks in the reservoir.

Total mercury concentrations (Table 1) in muscle tissue did not show a correlation with fish standard length and weight. The OrgHg concentrations in muscle were higher than those of InorgHg (detritivores: $\mathrm{t}=29.86, \mathrm{p}<0.0001$; algivores/ planktivores: $\mathrm{t}=12.90, \mathrm{p}<0.0001$; omnivores: $\mathrm{t}=4.61, \mathrm{p}=0.009$; carnivores: $\mathrm{t}=4.44, \mathrm{p}=0.011$ ), with the $\% O r g H g$ ranging from 57 to $98 \%$ (Fig. 2). The muscle InorgHg concentrations were highest in detritivores, intermediate in algivores/planktivores, and lowest in omnivores and carnivores (KW = 22.13; $\mathrm{p}<0.0001$ ). Meanwhile, OrgHg concentrations were highest in carnivores, intermediate in detritivores and lowest in algivores/ planktivores and omnivores $(\mathrm{KW}=19.01 ; \mathrm{p}<0.001)$. The highest \%OrgHg occurred in carnivorous fish, followed by the omnivores and algivores/planktivores, and the lowest percentages occurred in detritivores $(\mathrm{KW}=22.99$; $\mathrm{p}<0.0001)$ (Fig. 2).

As for the muscle, OrgHg concentrations in gonads were higher than those of InorgHg (detritivores: $t=6.60, p=0.003$; omnivores: $\mathrm{t}=62.94, \mathrm{p}<0.0001$ ) with \%OrgHg ranged from 83 to $99 \%$. The gonads contained less $\mathrm{THg}$ than any of the other tissues within each trophic level (gonad $v s$. liver: detritivores: $\mathrm{t}=5.85, \mathrm{p}<0.001$; omnivores: $\mathrm{t}=4.46, \mathrm{p}=0.007$; gonad $v$. muscle: detritivores: $\mathrm{t}=2.94, \mathrm{p}=0.026$; omnivores: $\mathrm{t}=3.57$, $\mathrm{p}=0.016)$. The kidney and gut showed higher $\mathrm{THg}$ concentrations than the gonads (Fig. 3).

In the liver, InorgHg concentrations were higher than OrgHg (detritivores: $\mathrm{t}=11.99, \mathrm{p}<0.001$; omnivores: $\mathrm{t}=8.68$, $\mathrm{p}=0.001$; carnivores: $\mathrm{t}=2.91, \mathrm{p}=0.033$ ). The $\%$ OrgHg ranged from 38 to $48 \%$; this was lower than the gonad (detritivores: $\mathrm{t}=105.10, \mathrm{p}<0.0001$; omnivores: $\mathrm{t}=38.34, \mathrm{p}<0.0001)$ and muscle percentages (detritivores: $\mathrm{t}=22.66, \mathrm{p}<0.001$; omnivores: $\mathrm{t}=17.53, \mathrm{p}<0.0001$; carnivores: $\mathrm{t}=63.49, \mathrm{p}<0.0001$ ) (Fig. 3). Kidney InorgHg concentrations were also higher than OrgHg (Figs. 3a-b), with \%OrgHg ranging from 24 to $47 \%$.

The gut could also be analyzed in these groups (carnivores and omnivores). In the carnivores, OrgHg concentrations were higher than InorgHg $(t=10.53, \mathrm{p}=0.002)$, with \%OrgHg ranging from 70 to $91 \%$ (Fig. 3b). On the other hand, the omnivores showed InorgHg concentrations higher than OrgHg $(t=5.99, p=0.004)$, with \%OrgHg ranging from 22 to $36 \%$ (Fig. 3a). The ratio of OrgHg concentrations in liver/gut showed a mean of 1.43 and 1.56 for omnivores and carnivores, respectively. OrgHg concentrations in liver were higher than in the gut for carnivores $(t=10.12, \mathrm{p}<0.001)$ and omnivores $(\mathrm{t}=2.57, \mathrm{p}=0.033)$.

\section{Discussion}

In the present study, the carnivorous fish showed higher ratios and concentrations of organic mercury in muscle than did fish of the other trophic levels, indicating a biomagnification process in Vigário reservoir. We observed a gradual increase of \%OrgHg in muscle tissue of the fish, following an increase in the frequency of occurrence of animal items in the diet. On the other hand, the inorganic mercury concentrations decreased with the increase in trophic level, suggesting that this mercury species did not biomagnify through the food web. Other authors have found similar results for freshwater (e.g., Watras et al., 1998; Palermo et al., 2002) and estuarine fishes (e.g., Baêta et al., 2006). This pattern is attributed to a trend of excessive accumulation of methylmercury by fish (the main OrgHg species in biological tissues), in comparison with InorgHg species (Ikingura \& Akagi, 1999). Moreover, methylmercury has a longer half-life than InorgHg in fish. In fact, OrgHg concentrations in muscle were always higher than InorgHg in the present study, in concordance with the higher bioaccumulation potential of the former mercury species.

According to Jernelöv \& Lann (1971), the main Hg source for aquatic biota is food ingestion, and its importance is relative to the organism's trophic position. In a tropical system, fish have a wide food spectrum and the fish assemblages are subdivided into a diverse array of trophic guilds. However, their feeding spectrums are frequently related (Lowe-McConnel, 1987), and food overlap is expected. In the present study, this situation was observed between different trophic levels (e.g., algae were present in the diets of algivores/planktivores, detritivores, and omnivores; insects were consumed by detritivores and carnivores). Therefore, the gradual (and not abrupt) increase of \%OrgHg and decrease of InorgHg concentrations, from detritivores to carnivores, observed herein might be an effect of food overlap among the fish trophic levels. We conclude that the precise identification of fish dietary items and the definition of their trophic level are important

Table 1. Minimum and maximum values of total mercury concentration (THg) in muscle, and sizes of fish from Vigário reservoir. (N) number of specimens analyzed.

\begin{tabular}{lccccc}
\hline \multicolumn{1}{c}{ Species } & $\mathrm{N}$ & Standard length $(\mathrm{cm})$ & Weight $(\mathrm{g})$ & Trophic level & THg $(\mu \mathrm{g} / \mathrm{kg}$ w.w.) \\
\hline Loricariichthys castaneus & 12 & $21.5-26.3$ & $80-135$ & Detritivores & $150-310$ \\
Rhamdia quelen & 10 & $19.5-24.5$ & $130-185$ & Omnivores & $44-121$ \\
Astyanax aff. bimaculatus & 22 & $9.7-11.0$ & $22-32$ & Algivores/Planktivores & $96-157$ \\
Oligosarcus hepsetus & 6 & $15.5-18.9$ & $55-89$ & Carnivores & $185-499$ \\
Hoplias malabaricus & 4 & $19.8-23.7$ & $200-360$ & & \\
\hline
\end{tabular}




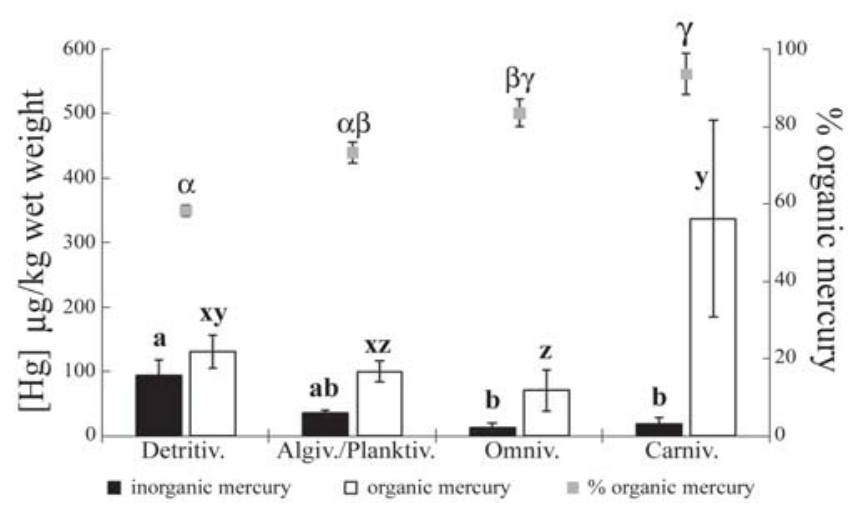

Fig. 2. Mean concentrations and ratios of mercury in muscle of fish collected from Vigário reservoir. Different letters indicate significant difference between groups: inorganic (ab) and organic mercury concentrations (xyz), and ratios of organic mercury $(\alpha \beta \gamma)$. Error bars represent the standard deviation of the mean.
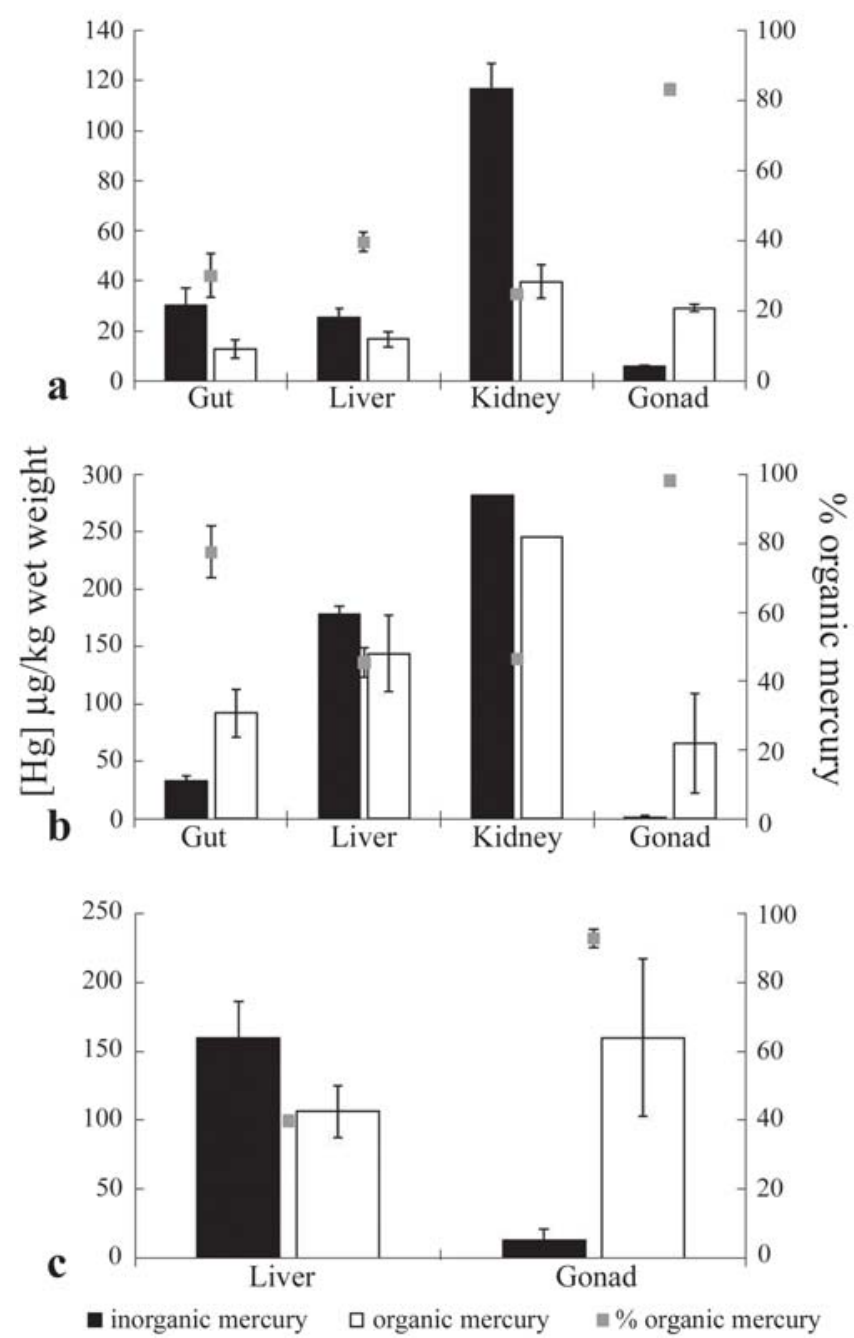

Fig. 3. Mean concentrations and ratios of mercury in different tissues of omnivorous (a), carnivorous (b), and detritivorous fishes (c) collected from Vigário Reservoir. Error bars represent one standard deviation of the mean. approaches in understanding the Hg dynamics in fish from tropical environments.

The detritivorous species stood out for their relatively high values of both organic and inorganic mercury concentrations. This trophic category has feeding habits that are closely associated with the bottom sediment (Moodie \& Power, 1982), and mercury concentrations in their muscle have been related to this compartment (Zhou \& Wong, 2000). The Vigário reservoir is a highly dendritic lake, and the water residence time is about 30 days. In addition, due to high eutrophication levels the water column is intensively colonized by macrophytes, whose decomposition decreases the dissolved oxygen concentration and $\mathrm{pH}$. Those environmental conditions are known to be favorable to $\mathrm{Hg}$ methylation in sediment. In fact, the detritivores from Vigário reservoir contain higher concentrations and ratios of OrgHg compared to similar fish from neighboring reservoirs (Lajes reservoir: [OrgHg] = 46 g/kg w.w.; \%OrgHg = 27\%; Santana reservoir: [OrgHg] = $40 \mu \mathrm{g} / \mathrm{kg}$ w.w.; \%OrgHg = 25\%; Palermo, 2008). Therefore, although they belong to a low trophic level (small amount of animal items in the diet), the detritivorous fish from Vigário reservoir probably are directly exposed to high loads of organic mercury. Moreover, this trophic level showed the highest InorgHg concentrations among the local fish species. This pattern is widely recognized (e.g., Palermo, 2008) and also attributed to the close relationship between the detritivores and the sediment. The lake bed is considered the major source of contaminants to these organisms (Farag et al., 1998), since this compartment is the sink of heavy metals in an aquatic system. Because of this direct relationship, detritivores are considered good indicators for mercury concentrations (organic and inorganic) in the sediment.

Of the fish tissues assessed herein, the gonads contained the least total mercury. This result corroborates other studies on mercury dynamics in fish, for example, in Czech Republic reservoirs (Svobodová et al., 1999) and Swedish lakes (Lindqvist et al., 1991). These low mercury concentrations in gonads could be explained by the biochemical characteristics of Hg in the organism. Mercury generally occurs in the body as water-soluble complexes (reviewed by Clarkson, 2002). Since the deposition of vitelline proteins in the teleost oocytes contributes a large proportion of its dry weight (Kunz, 2004) and this protein is a lipoglycophosphoprotein, a water-soluble complex does not possess affinity with gonads. Therefore, mainly liposoluble complexes (and, consequently, lipo-soluble Hg compounds) may be attached to the gonads. Water-soluble $\mathrm{Hg}$ compounds attach to sulfhydryl bonds present in the amino acids cysteine and methionine. However, those two amino acids are present only in an average of $7 \%$ of the content of fish egg proteins (Block \& Weiss, 1956). In consequence, the gonads do not possess a sulfur atom of thiol ligands in high quantities (such as muscle tissue, for example) that would facilitate mercury adsorption.

The gonad can eliminate mercury in eggs, and therefore 
the metal can be transferred from adult fish to their offspring (McKim et al., 1976). Besides the fact that the earliest stages of cell division are the most sensitive to $\mathrm{Hg}$ toxicity in the fish embryonic period, methylmercury is more toxic than InorgHg in this situation (Sharp \& Neff, 1982). In the present study, we found higher OrgHg concentrations than InorgHg in the gonads. Baêta et al. (2006) reported similar results in a study with estuarine fish from Guanabara bay (Brazil), which contained $100 \%$ of $\mathrm{Hg}$ in methylmercury form in the gonads. Hence, even at low THg concentrations, this metal in its organic form can cause profound disturbances in fish eggs and larval stages (Wiener \& Spry, 1996). Consequently, studies on $\mathrm{Hg}$ dynamics in the gonads may provide important supporting information for the understanding of the potential effects on fish reproduction and its reflection in the population dynamics of these organisms.

The InorgHg that reaches the digestive tract by food is not absorbed in high quantities and is eliminated in feces (10 to $27 \%$ absorption rates in fish). On the other hand, approximately 56 to $95 \%$ of OrgHg ingested as food is efficiently absorbed through the gut wall barrier (Wang \& Wong, 2003; Wiener et al., 2003). Less methylmercury is stored in the gut than is transferred to the circulatory system (Boudou \& Ribeyre, 1985). Nevertheless, we observed that this storage is proportional to the expected $\mathrm{Hg}$ in fish food. The gut concentrations and ratios, as in the muscle tissue, can also be related to food habit (highest in carnivorous fishes).

The absorbed OrgHg is transported via blood to all tissues and distributed in the different internal compartments (Wiener et al., 2003). The liver concentrates the pollutants absorbed by the digestive tract and shows a high bioaccumulation capacity, mainly because of metallothioneins. Finally, Hg can be eliminated by bile (Hogstrand \& Haux, 1991; Liao et al., 2006), reabsorbed in the gastrointestinal tract, and reach the liver, ending the enterohepatic circulation. In the present study, the higher OrgHg values in the liver in comparison to the gut exemplify the higher bioaccumulation potential by the former tissue. Due to the enterohepatic circulation, fish that receive high OrgHg concentrations from food would absorb it, leading to high accumulation of this metal by the liver. Hence, the trophic level would also affect the liver OrgHg concentrations.

The \%OrgHg in the liver is probably controlled by detoxification mechanisms. The main tissues responsible for Hg elimination and detoxification in fish are the kidney and the liver, respectively, which are actively involved in heavy-metal metabolism (Beckvar et al., 1996; Elia et al., 2003). Both organs showed higher inorganic than organic mercury concentrations in the present study. These results are similar to findings from other studies (e.g., Riisgard \& Hansen, 1990), which showed lower \%OrgHg in these two organs than in the muscle. Houserova et al. (2006) found methylmercury ratios (in relation to THg concentrations) from 23 to $48 \%$ and 16 to $37 \%$ in the liver and in the kidney, respectively. Baêta et al. (2006) found methylmercury ratios between 10 and $27 \%$ in the liver of three estuarine fish species. This pattern may be related to the detoxification process that would transform the organic to the inorganic form in an attempt to eliminate mercury, probably resulting in higher concentrations of InorgHg than OrgHg observed in these tissues.

We conclude that the distribution and dynamics of the different mercury species (organic and inorganic) in each fish tissue are consequences of their intrinsic biochemical and physiological characteristics. This differentiated bioaccumulation could also be strongly determined by the trophic position of these organisms in the food chain, as well as by the environmental conditions in which they reside.

\section{Acknowledgements}

The authors give thanks to Laboratório de Radioisótopos (UFRJ) and Núcleo de Estudos Limnológicos (UNIRIO) where this study was done. Elisabeth Leão for bibliography references about fishes, Helena A. Kehrig, Leonardo Coimbra and the anonymous reviewers for revision. This work was supported by LIGHT-RJ and CNPq (fellowship to D. Kasper).

\section{Literature Cited}

Aguiaro, T. \& E. P. Caramaschi. 1998. Trophic guilds in fish assemblages in three coastal lagoons of the Rio de Janeiro State (Brazil). Verhandlungen des Internationalen Verein Limnologie, 26: 2166-2169.

Baêta, A. P., H. A. Kehrig, O. Malm \& I. Moreira. 2006. Total mercury and methylmercury in fish from a tropical estuary. Pp. 183-192. In: Kungolos, A., C. A. Brebbia, C. P. Samaras \& V. Popov (Eds.). Environmental Toxicology. Boston, Wit Press, 362p.

Bargagli, R., F. Monaci, J. C. Sanchez-Hernandez \& D. Cateni. 1998. Biomagnification of mercury in an Antarctic marine coastal food web. Marine Ecology Progress Series, 169: 65-76.

Bastos, W. R., O. Malm, W. C. Pfeiffer \& D. Cleary. 1998. Establishment and analytical quality control of laboratories for $\mathrm{Hg}$ determination in biological and geological samples in the Amazon, Brazil. Ciência e Cultura, 50(4): 255-260.

Beckvar, N., J. Field, S. Salazar \& R. Hoff. 1996. Contaminants in aquatic habitats at hazardous waste sites: mercury. Seattle, National Oceanic and Atmospheric Administration, 64p.

Belger, L. \& B. R. Forsberg. 2006. Factors controlling Hg levels in two predatory fish species in the Negro River Basin, Brazilian Amazon. The Science of Total Environment, 367: 451-459.

Block, R. J. \& K. W. Weiss. 1956. Amino Acid Handbook. Springfield, Charles Thomas, 386p.

Boudou, A. \& F. Ribeyre. 1985. Experimental study of trophic contamination of Salmo gairdneri by two mercury compounds $\left(\mathrm{HCl}_{2}\right.$ and $\mathrm{CH}_{3} \mathrm{HgCl}$ )-analysis at the organism and organ levels. Water Air and Soil Pollution, 26: 137-148.

Branco, C. W. C., T. Aguiaro, F. A. Esteves \& E. P. Caramaschi. 1997. Food sources of the Teleost Eucinostomus argenteus in two coastal lagoons of Brazil. Studies on Neotropical Fauna and Environment, 32: 33-40.

Clarkson, T. W. 2002. The three modern faces of mercury. Environmental Health Perspectives, 110: 11-23. 
Elia, A. C., R. Galarini, M. I. Taticchi, A. J. M. Dörr \& L. Mantilacci. 2003. Antioxidant responses and bioaccumulation in Ictalurus melas under mercury exposure. Ecotoxicology and Environmental Safety, 55: 162-167.

Farag, A. M., D. F. Woodward, J. N. Goldstein, W. Brumbaugh \& J. S. Meyer. 1998. Concentrations of metals associated with mining waste in sediments, biofilm, benthic macroinvertebrates and fish from the Coeur d'Alene River Basin, Idaho. Archives of Environmental Contamination and Toxicology, 34: 119-127.

FEEMA, 1991. Qualidade das águas do estado do Rio de Janeiro 87-89. Bacia hidrográfica do rio Guandu, reservatórios de Funil, Santana, Vigário e Lajes. Rio de Janeiro, FEEMA, 180p.

Gomes, J. H. C., A. C. M. I. Dias \& C. W. C. Branco. 2008. Fish assemblage composition in three reservoirs in the state of Rio de Janeiro. Acta Limnologica Brasiliensia, 20(4): 117-130.

Hogstrand, C. \& C. Haux. 1991. Binding and detoxification of heavy metals in lower vertebrates with reference to metallothionein. Comparative Biochemistry and Physiology, 100: 137-141.

Houserova, P., V. Kuban, P. Spurny \& P. Habarta. 2006. Determination of total mercury and mercury species in fish and aquatic ecosystems of Moravian rivers. Veterinary Medicina, 51: 101-110.

Hyslop, E. J. 1980. Stomach contents analysis - a review of methods and their application. Journal of Fish Biology, 17: 411-429.

Ikingura, J. R. \& H. Akagi. 1999. Methylmercury production and distribution in aquatic systems. The Science of Total Environment, 234: 109-118.

Jernelöv, A. \& H. Lann. 1971. Mercury accumulation in food chains. Oikos, 22: 403-406.

Kehrig, H. A., M. Costa, I. Moreira \& O. Malm. 2001. Methylmercury and total mercury in estuarine organisms from Rio de Janeiro, Brazil. Environmental Science and Pollution Research, 8(4): 275-279.

Kehrig, H. A., T. G. Seixas, E. F. A. Palermo, A. P. Baêta, C. W. Castelo-Branco, O. Malm \& I. Moreira. 2009. The relationships between mercury and selenium in plankton and fish from a tropical food web. Environmental Science and Pollution Research, 16: 10-24.

Kunz, Y. W. 2004. Developmental Biology of Teleost Fishes. Springer, 636p.

Liao, C. Y., J. J. Fu, J. B. Shi, Q. F. Zhou, C. G. Yuan \& G. B. Jiang. 2006. Methylmercury accumulation, histopathology effects, and cholinesterase activity alterations in medaka (Oryzias latipes) following sublethal exposure to methylmercury chloride. Environmental Toxicology and Pharmacology, 22: 225-233.

Lindqvist, O., K. Johnasson, M. Aastrup, A. Andersson, L. Bringmark, G. Hovsenius, L. Hakanson, A. Iverfeldt, M. Meili \& B. Timm. 1991. Mercury in the Swedish environment: Recent research on causes, consequences and corrective methods. Water, Air and Soil Pollution, 55: 1-251.

Lowe-McConnel, R. H. 1987. Ecological studies in tropical fish communities. Cambridge, Cambridge University Press, 400p.

Maury-Brachet, R., G. Durrieu, Y. Dominique \& A. Boudou. 2006. Mercury distribution in fish organs and food regimes: significant relationships from twelve species collected in French Guiana (Amazon basin). The Science of the Total Environment, 368: 262-270.

McIntyre, J. K. \& D. A. Beauchamp. 2007. Age and trophic position dominate bioaccumulation of mercury and organochlorines in the food web of Lake Washington. Science of the Total Environment, 372: 571-584.
McKim, J. M., G. F. Olson, G. W. Holcombe \& E. P. Hunt. 1976. Long-term effects of methylmercuric chloride on three generations of brook trot (Salvelinus fontinalis): toxicity, accumulation, distribution, and elimination. Journal Fisheries Research Board of Canada, 33: 2726-2739.

Moodie, G. E. E. \& M. Power. 1982. The reproductive biology of an armoured catfish, Loricaria uracantha, from Central America. Environment Biology of Fish, 7: 143-148.

Novakowski, G. C., N. S. Hahn \& R. Fugi. 2007. Alimentação de peixes piscívoros antes e após a formação do reservatório de Salto Caxias, Paraná, Brasil. Biota Neotropica, 7(2): 149-154.

Palermo, E. F. A. 2008. Acúmulo e transporte de mercúrio em reservatórios tropicais. Unpublished Ph.D. Dissertation, Universidade Federal do Rio de Janeiro, Rio de Janeiro, 96p.

Palermo, E. F. A., H. A. Kehrig, C. W. C. Branco, O. Malm \& H. S. B. Santos. 2002. Mercúrio e Metilmercúrio em plâncton, peixe, material particulado em suspensão e sedimento superficial de um antigo reservatório tropical, Brasil. Pp. 217-219. In: Prego, R., A. Duarte, A. V. Pantelitchouk \& T. R. Santos (Eds.). Estudos sobre contaminação ambiental na Península Ibérica. Viseu, Piaget, 300p.

Riisgard, H. U. \& S. Hansen. 1990. Biomagnification of mercury in a marine grazing food-chain: algal cells Phaeodactylum tricornutum, mussels Mytilus edulis and flounders Platichthys flesus studied by means of a stepwise-reduction-CVAA method. Marine Ecology Progress Series, 62: 259-270.

Sánchez-Botero, J. I., R. P. Leitão, E. P. Caramaschi \& D. S. Garcez. 2007. The aquatic macrophytes as refuge, nursery and feeding habitat for freshwater fish from Cabiúnas lagoon, Restinga de Jurubatiba National Park, Rio de Janeiro, Brazil. Acta Limnologica Brasiliensia, 19(2): 143-153.

Schetagne, R., J. F. Doyon \& J. J. Fournier. 2000. Export of mercury downstream from reservoirs. The Science of the Total Environment, 260: 135-145.

Sharp, J. R. \& J. M. Neff. 1982. The toxicity of mercuric chloride and methylmercuric chloride to Fundulus heteroclitus embryos in relation to exposure conditions. Environmental Biology of Fishes, 7: 277-284.

Stemberger, R. S. \& C. Y. Chen. 1998. Fish tissue metals and zooplankton assemblages of northeastern U.S. lakes. Canadian Journal of Fisheries and Aquatic Sciences, 55: 339-352.

Svobodová, Z., L. Dusek, M. Hejtmánek, B. Vykusová \& R. Smíd. 1999. Bioaccumulation of mercury in various fish species from Orlík and Kamýr Reservoirs in the Czech Republic. Ecotoxicology and Environmental Safety, 43: 231-240.

Uthe, J. F., J. Solomon \& B. Grift. 1972. Rapid semimicro method for the determination of methylmercury in fish tissue. Journal of the Association of Official Analytical Chemists, 55(3): 583-589.

Vazzoler, A. E. A. M. 1996. Biologia da reprodução de peixes teleósteos: teoria e prática. Maringá/São Paulo, EDUEM/SBI, 169p.

Wang, W. X. \& R. S. K. Wong. 2003. Bioaccumulation kinetics and exposure pathways of inorganic mercury and methylmercury in a marine fish, the sweetlips Plectorhinchus gibbosus. Marine Ecology Progress Series, 261: 257-268.

Watras, C. J., R. C. Back, S. Halvorsen, R. J. M. Hudson, K. A. Morrison \& S. P. Wente. 1998. Bioaccumulation of mercury in pelagic freshwater food webs. The Science of the Total Environment, 219: 183-208.

Wiener, J. G., D. P. Krabbenhoft, G. H. Heinz \& A. M. Scheuhammer. 2003. Ecotoxicology of mercury. Pp. 409-463. In: Hoffman, D. J., B. A. Rattner, G. A. Burton \& J. Cairns (Eds.). Handbook of Ecotoxicology. Boca Raton, Lewis Publishers, 1290p. 
Wiener, J. G. \& D. J. Spry. 1996. Toxicological significance of mercury in freshwater fish. Pp. 297-339. In: Beyer, W. N., G. H. Heinz \& A. W. Redmon-Norwood (Eds.). Environmental contaminants in wildlife: Interpreting tissue concentrations. Boca Raton, Lewis Publishers, 512p.

World Health Organization. 1990. Environmental Health Criteria 101: Methylmercury. Geneva, WHO/IPCS, 144p.

Zar, J. H. 1984. Biostatistical analisys. New Jersey, Prentice Hall, 718p.

Zhou, H. Y. \& M. H. Wong. 2000. Mercury accumulation in freshwater fish with emphasis on the dietary influence. Water Research, 34(17): 4234-4242.

Accepted July 10, 2009

Published December 18, 2009 